\title{
Reaction of families and lines of melon to powdery mildew
}

\author{
Rui Sales Júnior ${ }^{1}$; Glauber HS Nunes ${ }^{1}$; Sami J Michereff ${ }^{2}$; Elaíne WL Pereira ${ }^{1}$; Izabel M Guimarães ${ }^{1}$ \\ ${ }^{1}$ UFERSA, C. Postal 137, 59625-900 Mossoró-RN; glauber@ufersa.edu.br; ${ }^{2}$ UFRPE-Depto. Agronomia, Av. Dom Manoel de Medeiros, \\ s/n, 52171-900 Recife-PE; sami@depa.ufrpe.br
}

\begin{abstract}
Powdery mildew, caused by Podosphaera xanthii, is an important disease of melon in the Brazilian Northeast. The objective of this work was to evaluate the reaction of families, lines and cultivars of melon to $P$. xanthii. Two experiments in simple lattice were carried out under field conditions in the municipalities of Mossoró and Baraúna to evaluate 144 families. In a greenhouse, an experiment was carried out in a completely randomized design to evaluate 19 lines and the cultivars Yellow Queen, Chilton and Hy Mark. Disease was assessed by a severity scale. There was genetic variability among families. The families $4,5,11,14,18,23,33,42,101,112$ and 140 were identified in both sites as resistant. The lines LOF-027, LOF105, LPS-124, MEL-008 and cultivar Chilton showed resistance to race 1 of the fungus.
\end{abstract}

Keywords: Cucumis melo, Podosphaera xanthii, powdery mildew, resistance, selection.

\section{RESUMO}

\section{Reação de famílias e linhagens de melão ao oídio}

O oídio, causado por Podosphaera xanthii, é uma importante doença do melão no Nordeste brasileiro. O objetivo do presente trabalho foi avaliar a reação de famílias, linhagens e cultivares de melão a $P$. xanthii. Foram conduzidos, em condições de campo, nos municípios de Mossoró e Baraúna, experimentos em látice simples para avaliar 144 famílias. Em casa de vegetação, foi conduzido um experimento em delineamento inteiramente casualizado para avaliar 19 linhagens e as cultivares Yellow Queen, Chilton e Hy Mark. A severidade da doença foi avaliada mediante uma escala de notas. Houve variabilidade genética entre as famílias. Foram identificadas como resistentes, em ambos os locais, as famílias 4, 5, 11, 14, 18, 23, $33,42,101,112$ e 140. As linhagens LOF-027, LOF-105, LPS-124, MEL-008 e a cultivar Chilton mostraram resistência à raça 1 do fungo.

Palavras-chave: Cucumis melo, Podosphaera xanthii, oídio, resistência, seleção.

\section{(Recebido para publicação em 18 de novembro de 2009; aceito em 1 de março de 2011)} (Received on November 18, 2009; accepted on March 1, 2011)

$\mathrm{T}$ he melon (Cucumis melo L.) is the most important crop for agribusiness in Rio Grande do Norte State. The area cultivated with this vegetable expands every year because of the high prices for the product on the external market. The climatic conditions of high temperatures, high insolation levels, little rainfall for most of the year and the highly technological melon cropping are the main reasons for the national importance of Rio do Norte State (Nunes et al., 2005).

Increased cropping area and intensive continuous cultivation have contributed to increasing plant health problems in the melon in the Brazilian Northeast. Powdery mildew, a disease caused by Podosphaera (Sphaerotheca) xanthii (Castag.) U. Braun \& Shish, is the main fungus problem that affects the melon canopy. This disease occurs mainly in periods of low relative air humidity and high temperatures (Fazza, 2006).

Under ideal development conditions for the fungus, the severely attacked plants lose vigor and there is premature leaf fall and consequently reduced yield. This reduction is due to decrease in the leaf area for photosynthesis (Stadnik et al., 2001), that damages the crop yield because of the decrease in size, number and quality of the fruits produced (Viana et al., 2001).

Melon powdery mildew has been controlled by applying sulfur-based fungicides. In Brazil, the fungicides used to control powdery mildew represent a considerable part of the market and increase the production cost of the crop. On the other hand, the importance of alternative control methods has increased significantly due to pressure from consumers for products with low quantities of agricultural chemical residues and reduced environmental contamination.

One of the alternatives to control powdery mildew is using cultivars with genetic resistance that have the main advantages of easy adoption by the producer, use in integrated disease management programs and environmental conservation. In the case of powdery mildew, control by genetic resistance is complicated because there are races in the pathogen population. Many cultivars have been released by the genetic breeding programs developed in some countries of the world. However, because of the variability present in the $P$. xanthii species the resistance of the cultivar is quickly broken and hinders research (Fukino et al., 2004). The $P$. xanthii population usually consists of a mix of races (Hosoya et al., 1999; Hosoya et al., 2000; Kuzuya et al., 2003; McGreight, 2006) that alters in function of the cultivar planted and the cropping season (Fukino et al., 2004) requiring continuous monitoring of the variability of the referred pathogen. In Brazil, race 1 has been identified by several authors (Reifschneider et al., 1985; Reis et al., 2002; Reis et al., 2005). Race 2 was first observed in São Paulo in 2000 (Kobori et al., 2004) and then in the Federal District (Reis \& Buso, 2004), Petrolina (Kobori et al., 2005) and in the Mossoró-Assu Agricultural 
Pole (Fazza, 2006). Fazza (2006) also reported the occurrence of races $0,3,4$ and 5 at a lower frequency compared to races 1 and 2 .

Understanding of the genetic control of the resistance is very important to obtain cultivar resistance to a determined pathogen. For the case of the pathosystem in question, different genetic models have been proposed for melon resistance to races 1,2 and 5 of $P$. xanthii. Resistance to race 1 seems to be controlled by one or two genes (Kenigsbuch \& Cohen, 1992; Epinat et al., 1993; Floris \& Álvarez, 1996; McGreight, 2003). Genetic control of the resistance to race 2 is more complex because the resistance is partial and there are modifiers (McGreight et al., 1987 Epinat et al., 1993). Resistance to race 5, studied in the PI 124112 accession, is controlled by a single dominant gene (Bardin et al., 1999). Recently, Yuste-Lisbona et al. (2010) studied resistance of the TGR-1551 genotype to races 1, 2 and 5 and concluded that two independent genes, one dominant and one recessive (dominant-recessive epistasis) are involved in the genetic control of resistance to these races. This manuscript was indicated by the authors as the first report of the existence of a recessive gene that conferred resistance to more than one $P$. xanthii race. The discrepant results among the articles in the literature are due to the genetic variability of the pathogen, the parents involved, the assessment methodology and different environmental conditions.

Thus the objective of the present study was to assess the reaction of melon families of the Galia type and melon lines of the Yellow, Honey Dew and Frog Skin types to the P. xanthii fungus.

\section{MATERIAL AND METHODS}

Field assessment - Two field experiments were carried out in the municipalities of Mossoró and Baraúna, Rio Grande do Norte State, Brazil. The climate in the two municipalities, according to the Köppen classification, is 'BSWh' (very dry with a wet season in the summer that extends to the fall/ autumn) (Carmo Filho \& Oliveira, 1989).
A total of 144 S6 Gália melon families was assessed derived from a cross between the DRG-1537 and AMR04 hybrids. Both are single hybrids with andromonoecious sexual expression. The DRG-1537 hybrid is the Gália type, with round fruit, average weight around $1.5 \mathrm{~kg}$, white flesh, non-aromatic, high total soluble solids value (12-13 ${ }^{\circ}$ Brix), resistance to race 1 of $P$. xanthii and race 1 of Fusarium oxysporum f. sp. melonis. The AM-04 hybrid is the Yellow type, spherical in shape, average weight 1.7 $\mathrm{kg}$, wrinkled yellow skin, white flesh, high flesh firmness values, total soluble solids content (12 and $14^{\circ}$ Brix) and is resistant to Myrothecium roridum, race 2 of $P$. xanthii and to race 1 of $F$. oxysporum f. sp. melonis.

Self-pollination was begun in the field with a population of 580 plants. The self-pollinating generations where advanced by the Single Seed Descendent method or SSD. There were five generations of self-pollination. When the families were in the S6 generation, selection was made in augmented blocks for fruit quality, earliness and yield, resulting in 144 families.

The soil in the two experiments was prepared by plowing and grading, then furrowed in rows approximately $20 \mathrm{~cm}$ deep spaced at $2.0 \mathrm{~m}$ and fertilized with cattle manure at doses of 10 and $12 \mathrm{tha}^{-1}$, in Mossoró and Baraúna, respectively.

The seeds were sown in extruded polystyrene trays with 128 wells. The seedlings were transplanted 15 days after sowing in Mossoró and 11 days after sowing in Baraúna. The crop was spray irrigated with a volume of approximately $3,000 \mathrm{~m}^{3} \mathrm{ha}^{-1}$ throughout the crop cycle. The other crop practices were carried out according to management recommendation for the crop in the State (Nunes et al., 2004).

A single 12 × 12 lattice design was used and the plot was formed by two $5.0 \mathrm{~m}$ lines. The spacing adopted was $2.0 \times 0.5 \mathrm{~m}$, totaling 20 plants per plot. The disease severity characteristic was assessed, using a scale of scores ranging from 1 to 5 , where $1=$ no symptom; $2=$ $0.1 \%$ to $10 \%$ leaf area affected; $3=11 \%$ to $25 \%$ leaf area affected; $4=26 \%$ to $50 \%$ leaf area affected; $5=$ over $50 \%$ leaf area affected. The assessment was made
43 days after transplanting the seedlings to the field on 10 randomly chosen leaves. The disease occurred naturally and uniformly in the field. The severity was assessed by four experienced assessors working independently who were experienced in the melon crop. The assessment means were used for the statistical analyses.

The individual (per location) and joint analyses were carried out considering the location effect as fixed and plot and family as random effect. The components of variance were estimated by the restricted maximum likelihood (REML) using the PROC MIXED procedure in $\mathrm{SAS}^{\circledR} 9.1$ for Windows. The heredity in the broad sense and selection gains were estimated according to the expressions reported by Bernado (2000). A 10\% selection intensity was used to select the lines.

Assessment in the greenhouse Nineteen melon lines and the Yellow Queen, Chilton and Hy Mark cultivars were assessed in a greenhouse in a complete randomized design with six replications. The lines with the LOF code are the Orange Flesh type and were obtained from a population derived from the Honey Dew Red Flesh, Saturn, Orange Flesh and HT-01 cultivar. The lines with the LPS code are the Frog Skin type and are derived from the cross of the HPS-07 and Tendency hybrids, both the Frog Skin type. The lines with the MEL code are the yellow type and derived from the AMR-02 x Gold Mine hybrid cross, both yellow type.

The plot consisted of a $5 \mathrm{~L}$ pot with one plant and the substrate consisted of 2:1 sterilized soil and cattle manure. Plants isolated from the Yellow Queen hybrid, highly susceptible to powdery mildew, were inoculated 15 days before installing the experiment with an isolate of race 1 of the fungus. These plants served as an inoculum source. The inoculation was made with $3 \mathrm{~cm}$ diameter circles of infected leaf from the same hybrid placed on the adaxial part of the leaves of the genotypes at 35 days after sowing.

Assessment was made 15 days after inoculation with race 1 , following the scale of scores used in the field experiment. The Kruskal-Wallis 
nonparametric test was applied with the nominal level of significance of $5 \%$ probability $(\alpha=0.05)$. A test was applied of comparison of mean rankings to distinguish the treatments. The SAEG program was used for all the analyses (Ribeiro Júnior, 2001).

\section{RESULTS AND DISCUSSION}

Field assessment - The means of the two locations were not significantly different. Considering the scale of scores applied, on average, the lines had between 26 and $50 \%$ of the leaf area affected and were considered susceptible to the pathogen.

Assuming that the families represented a random, representative sample of the population, components of variance were estimated for this source of variation. The positive and significant estimates of the genetic variances indicated that there was genetic heterogeneity among the families in the two locations and in the mean of the two locations for reaction to the pathogen (Table 1). Detecting differences among the families in the two locations and in the joint analysis was an important result from the pragmatic point of view because the presence of variability is an essential condition for selection and consequent obtaining of genetic gain.

On the other hand, even with the genetic variability present among the families, the heredity estimates in the broad sense were low, especially in Mossoró. In the present study, the magnitude of the heredity estimates showed the significant effect of environment acting on the traits analyzed (Falconer \& McKay, 1996). The coefficient of variation values indicated great instability in the variable (Sampaio, 2002) that corroborated with the heredity magnitudes. The genetic gains with selection were small in consequence of the low heredity values. Nevertheless, families with excellent fruit characteristics and scores between 1 and 3 were selected for assessment in subsequent stages of the program (Table 2). The families that were outstanding in the two assessment locations were 4, 5, $11,14,18,23,33,42,101,112$ and 140 with means between 1 and 2 . All these

Table 1. Estimates of residual variance, genetic variance among families, variance of family $\mathrm{x}$ site interaction, broad-sense heritability and genetic gain with selection of reaction to $P$. xantii of melon families (estimativas da variância residual, variância genética entre famílias, variância da interação família x local, herdabilidade no sentido amplo e ganho genético com a seleção da reação a Podosphaera xantii de famílias de meloeiro). Mossoró, UFERSA, 2005.

\begin{tabular}{lccccccc}
\hline Local & Medium & $\mathbf{C V}(\%)$ & $\hat{\sigma}_{e}^{2}$ & $\sigma_{g e n}^{\hat{2}}$ & $\hat{\sigma}_{\boldsymbol{p}}^{2}$ & $\hat{h^{2}}$ & $\hat{G}_{S}$ \\
\hline Mossoró & 4.20 & 29.37 & 0.883 & $0.283^{*}$ & - & 24.28 & 10.71 \\
Baraúna & 3.73 & 26.74 & 0.533 & $0.467^{*}$ & - & 46.70 & 21.73 \\
Conjunta & 3.97 & 27.00 & 0.643 & $0.440^{*}$ & 0.0 & 40.62 & 18.64 \\
\hline
\end{tabular}

$\hat{\sigma_{e}^{2}}=$ residual variance (variância residual); $\sigma_{\text {gen }}^{\hat{2}}=$ genetic variance among families (variância genética entre famílias); $\hat{\sigma}_{\boldsymbol{p}}^{2}=$ family by site interaction variance (variância da interação família x local); $\hat{h^{2}}=$ broad-sense heritability (herdabilidade no sentido amplo); $\hat{G}_{S}=$ genetic gain with selection (ganho com a seleção); *Significant by Wald's test to probability of 5\% (significativo a $5 \%$ de probabilidade pelo teste de Wald).

Table 2. Distribution of melon families to powdery mildew in two municipalities of MossoróAssu agro-industrial complex (distribuição das famílias de meloeiro quanto à reação a oídio avaliadas em dois municípios do Agropolo Mossoró-Assu). Mossoró, UFERSA, 2005.

\begin{tabular}{|c|c|c|c|}
\hline \multirow{2}{*}{$\begin{array}{l}\text { Interval } \\
\text { (grade) }\end{array}$} & \multirow{2}{*}{$\begin{array}{c}\text { Resistance } \\
\text { class }\end{array}$} & \multicolumn{2}{|c|}{ Local } \\
\hline & & Mossoró & Baraúna \\
\hline$[1 ; 2)$ & Resistant & $\begin{array}{l}4,5,11,14,18,23,33, \\
42,101,112,138,139, \\
140,142\end{array}$ & $\begin{array}{l}4,5,11,14,18,23,33,42, \\
101,112,140,141\end{array}$ \\
\hline$[2 ; 3)$ & $\begin{array}{l}\text { Intermediate } \\
\text { resistance }\end{array}$ & $1,2,3,6,17$ & $1,2,3,6,17,28$ \\
\hline$[3 ; 4)$ & Susceptible & $\begin{array}{l}10,13,51,52,53,59, \\
60,61,63,78,79,83, \\
82,130,133,135,137, \\
144\end{array}$ & $\begin{array}{l}10,13,51,52,53,59,60, \\
61,63,78,79,83,82,130, \\
138,139,142\end{array}$ \\
\hline$[4 ; 5]$ & $\begin{array}{l}\text { Highly } \\
\text { susceptible }\end{array}$ & All others & All others \\
\hline
\end{tabular}

families presented practically no disease symptoms. Considering that during the experiment, only races 1 and 2 were identified by differentiator inoculation using only seven isolates per location, it could be inferred at first that the families that showed resistance combined the phenotype of the parents, because the DRG-1537 hybrid is resistant to race 1 and the AM-04 hybrid to race 2 of P. xanthii. Nevertheless, the resistance of the families should be confirmed by inoculating them with races 1 and 2 under controlled conditions. In Brazil, race 1 has been identified by several authors (Reifschneider et al., 1985; Reis et al., 2002; Reis et al., 2005). Race 2 was first observed in São Paulo in 2000 (Kobori et al., 2004) and was later reported in the Federal District (Reis \& Buso, 2004), Petrolina (Kobori et al., 2005) and the Mossoró-Assu Agribusiness Pole (Fazza, 2006).

On the other hand, some families, for example 138, presented resistance in one environment and susceptibility in the other (Table 2). Families with opposite responses to each environment may indicate the existence of more races in the two assessment environments. Two factors corroborate this interpretation; the first is the fact that other races in addition to races 1 and 2 have already been identified in the MossoróAssu Agribusiness Pole. Fazza (2006) assessed isolates from the Brazilian Northeast and observed prevalence of races 1 and 2 and the less frequent 
Table 3. Reaction to powdery mildew in melon lines and cultivars evaluated in greenhouse (reação a oídio de linhagens e cultivares de melão avaliados em casa de vegetação. MossoróRN. 2005). Mossoró. UFERSA. 2005.

\begin{tabular}{|c|c|c|c|c|}
\hline Genotype & Botanic group & Commercial type & $\begin{array}{l}\text { Average } \\
\text { ranking }^{1}\end{array}$ & $\begin{array}{c}\text { Average } \\
\text { (grade) }\end{array}$ \\
\hline Chilton & Cantaloupensis & Cantaloupe & $9.0 \mathrm{a}$ & 2.1 \\
\hline Y. Queen & Inodorus & Amarelo & $43.0 \mathrm{~b}$ & 4.7 \\
\hline Hy Mark & Cantaloupensis & Cantaloupe & $43.0 \mathrm{~b}$ & 4.7 \\
\hline UFERSA-05 & Conomon & ND & $27.0 \mathrm{~b}$ & 4.5 \\
\hline LOF-019 & Inodorus & Honey dew & $73.0 \mathrm{~b}$ & 5.0 \\
\hline LOF-027 & Inodorus & Honey dew & $9.0 \mathrm{a}$ & 2.1 \\
\hline LOF-105 & Inodorus & Honey dew & $19.0 \mathrm{a}$ & 2.3 \\
\hline LOF-145 & Inodorus & Honey dew & $73.0 \mathrm{~b}$ & 5.0 \\
\hline LOF-146 & Inodorus & Honey dew & $73.0 \mathrm{~b}$ & 5.0 \\
\hline LOF-149 & Inodorus & Honey dew & $43.0 \mathrm{~b}$ & 4.7 \\
\hline LOF-151 & Inodorus & Honey dew & $43.0 \mathrm{~b}$ & 4.7 \\
\hline LOF-201 & Inodorus & Honey dew & $73.0 \mathrm{~b}$ & 5.0 \\
\hline LOF-202 & Inodorus & Honey dew & $73.0 \mathrm{~b}$ & 5.0 \\
\hline LOF-203 & Inodorus & Honey dew & $73.0 \mathrm{~b}$ & 5.0 \\
\hline LOF-210 & Inodorus & Honey dew & $43.0 \mathrm{~b}$ & 4.7 \\
\hline LOF-219 & Inodorus & Honey dew & $43.0 \mathrm{~b}$ & 4.7 \\
\hline LPS-060 & Inodorus & Pele de sapo & $33.0 \mathrm{~b}$ & 3.7 \\
\hline LPS-089 & Inodorus & Pele de sapo & $73.0 \mathrm{~b}$ & 5.0 \\
\hline LPS-124 & Inodorus & Pele de sapo & $15.0 \mathrm{a}$ & 2.2 \\
\hline MEL-008 & Inodorus & Amarelo & $3.0 \mathrm{a}$ & 1.9 \\
\hline MEL-112 & Inodorus & Amarelo & $73.0 \mathrm{~b}$ & 5.0 \\
\hline MEL-128 & Inodorus & Amarelo & $43.0 \mathrm{~b}$ & 4.7 \\
\hline$\chi^{2}$ & & & & $\chi^{2}=44.00^{* 2}$ \\
\hline
\end{tabular}

${ }^{1}$ Average ranks followed by the same letter did not differ from each other by Kruskal-Wallis test at 5\% probability; ${ }^{2}$ Value of Qui-square (ordenamentos médios seguidos pela mesma letra não diferem entre si pelo Teste de Kruskal-Wallis a 5\% de probabilidade; ${ }^{2}$ Valor de Qui-quadrado).

occurrence of races $0,3,4$ and 5 . The second fact is the small number of isolates used in the two environments to monitor the race frequency, only seven in each location. Indeed, it can be questioned whether the small sample allowed the identification of the most prevalent races (1 and 2) but the less frequent races could not be identified, a fact observed by Fazza (2006) because of the greater number of isolates collected, 65 in total.

Family $\mathrm{x}$ location interaction was not observed, as can be observed by the nil estimates of the component of variance of the interaction (Table 1). Absence of the interaction showed consistent performance of the genotypes in the assessment environments, a resistant in at least one environment to other races found in the Mossoró-Assu Agribusiness Pole.

Assessment in the greenhouse Very high disease severity was observed in the assessment of the lines in the greenhouse, with an average of 4.17, where the chlorotic spots resulting from the severe leaf infection became necrotic. According to Sitterly (1978), powdery mildew is more severe in the greenhouse than in the field because of the reduced air circulation, low light intensity and higher temperatures.

According to the results obtained (Table 3 ), only $26.32 \%$ of the genotypes assessed in the greenhouse presented scores of less than 3.0. The lines/ cultivars with the lowest severity means were LOF-027, LOF-105, LPS-124, MEL-008 and Chilton.

Regarding race 1 of $P$. xanthii, Stadnik et al. (2001) reported that the Brazilian melon cultivars of the yellow type with resistance include the AF-646, AF-682 and Frevo hybrids and the other cultivars assessed were susceptible. Similarly, when assessing melon hybrids of the inodorous group under field conditions, Tendency, Frog Skin type, was severely attacked by powdery mildew, with decrease in the leaf area and consequently in the soluble solid content of around $4^{\circ}$ Brix. Santos et al. (2004) assessed the reaction of 20 melon hybrids under field conditions in municipalities in the States of Rio Grande do Norte and Ceará and observed that the hybrids were severely attacked by the fungus except for the hybrids CNPAT 32 x 02 hybrid, that was little affected and the TSX 32096 and PX 4910606 hybrids, that were moderately infected by powdery mildew.

There are few reported experimental results for race 2 of $P$. xanthii. Fazza (2006) assessed the reaction of commercial melon hybrids cultivated in Brazil to race 2 and observed that most were resistant.

The resistant materials in the greenhouse had good fruit characteristics such as high flesh firmness values, flesh thickness and soluble solid content. These lines could be used as germplasm and/or as single hybrid parents in subsequent stages of the program. 


\section{ACKNOWLEDGEMENT}

The authors thank the National Council for Scientific and Technological Development for funding the study, process number CNPq 477787/2006-1; Grant PQ 307396/2006-1 and CNPq 501660/2007-0.

\section{REFERENCES}

BARDIN MC; DOGIMONT P; NICOT P; PITRAT M. 1999. Genetic analysis of resistance of melon line PI 124112 to Sphaerotheca fuliginea and Erysiphe cichoracearum studied in recombinant inbred lines. Acta Horticulture 492: $163-168$

BERNARDO R. 2000. Breeding for quantitative traits loci in plants. Woodbury: Stemma Press. 369p.

CARMO FILHO F; OLIVEIRA OF. 1989. Mossoró: um município do semi-árido nordestino - características e aspectos florísticos. Mossoró: ESAM. 62p. (Coleção Mossoroense, Série B, n. 672).

EPINAT C; PITRAT M, BETRAND F. 1993. Genetic analysis of resistance of five melon lines to powdery mildews. Euphytica 65: $135-144$

FALCONER DS; MACKAY TFC. 1996. Introduction to quantitative genetics. 4. ed. London: Longman. $464 \mathrm{p}$.

FAZZA AC. 2006. Caracterização e ocorrência de agentes causais de oídio em cucurbitáceas no Brasil e reação de germoplasma de meloeiro. Piracicaba: ESALQ/USP. 60p. (Tese doutorado).

FLORIS E; ALVAREZ JM. 1996. Nature of resistance of seven melon lines to Sphaerotheca fuliginea. Plant Pathology 45: 155-160.

FUKINO N; KUNIHISA M; MATSUMOTO S. 2004. Characterization of recombinant inbred lines derived from crosses in melon (Cucumis melo L.) 'PMAR N ${ }^{\circ} 5$ ' $\mathrm{x}$ 'Harukei $\mathrm{N}^{\circ} 3$ '. 2004. Breeding Science 54: 141-145.

HOSOYA K; KUZUYA M; MURAKAMI
T; KATO K; NARISAWA K; EZURA H. 2000. Impact of resistant melon cultivars on Sphaerotheca fuliginea. Plant Breeding 119: 286-288.

HOSOYAK; NARISAWAK; PITRAT M; EZURA H. 1999. Race identification in powdery mildew (Sphaerotheca fuliginea) on melon (Cucumis melo) in Japan. Plant Breeding 118: 259-262.

KENIGSBUCH D; COHEN Y. 1992. Inheritance and allelism of genes for resistance to races 1 and 2 of Sphaerotheca fuliginea in muskmelon. Plant Disease 76: 626-629.

KOBORI RF; SUZUKI O; WIERZBICKI R; VECCHIA PTD; CAMARGO LEA. 2004. Occurrence of Podosphaera xanthii race 2 on Cucumis melo in Brasil. Plant Disease 88: 1161 (resumo).

KOBORI RF; SUZUKI O; WIERZBICKI R; VECCHIA PTD; CAMARGO LEA. 2005. Ocorrência da raça 2 de Sphaerotheca fuliginea em melão no estado de Pernambuco. Summa Phytopathologica 31: 20 (resumo).

KUZUYA M; HOSOYA K; YASHIRO K; TOMITA K; EZURA H. 2003. Powdery mildew (Sphaerotheca fuliginea) resistance in melon at the haploid level. Journal of Experimental Botany 54: 1069-1074.

McGREIGHT JD. 2003. Genes for resistance to powdery mildew races 1 and 2 U.S. in melon PI 313970. HortScience 38: 591-594.

McGREIGHT JD; PITRAT M; THOMAS AN; KISHABA N; BOHN GW. 1987. Powdery mildew resistance genes in muskmelon. Journal American Society Science 112: 156-160.

McCREIGHT JD. 2006. Melon-powdery mildew interactions reveal variation in melon cultigens and Podosphaera xanthii races 1 and 2. Journal American Society Horticulture. 131: $59-65$.

NUNES GHS; SANTOS JÚNIOR JJ; ANDRADE FV; BEZERRA NETO F; MENEZES J.B.; PEREIRA EWL. 2005. Desempenho de híbridos do grupo inodorus em Mossoró. Horticultura Brasileira 23: 90-94.

NUNES GHS; SANTOS JÚNIOR JJS; VALE FA; BEZERRA NETO F; ALMEIDA AHB; MEDEIROS DC. 2004. Aspectos produtivos e de qualidade de híbridos de melão cultivados no agropolo Mossoró-Assu. Horticultura Brasileira 22: 744-747.

REIFSCHNEIDER FJB; BOITEUX LS; OCCHIENA EM. 1985. Powdery mildew of melon (Cucumis melo) caused by Sphaerotheca fuliginea in Brazil. Plant Disease 69: 10691070.

REIS A; BUSO JA. 2004. Levantamento preliminar de raças de Sphaerotheca fuliginea no Brasil. Horticultura Brasileira 22: 462-465.

REIS A; BUSO JA; VIEIRA JV. 2002. Seleção de linhagens de melão do tipo Valenciano para resistência a Sphaerotheca fuliginea raça 1. Fitopatologia Brasileira 27: 156 (resumo).

REIS A; DIAS RCS; ARAGÃO FAZ; BOITEUX LS. 2005. Caracterização do perfil patogênico de isolados de Podosphaera xanthii obtidos em cucurbitáceas na região nordeste do Brasil. Horticultura Brasileira 23: 362 (resumo).

RIBEIRO JÚNIOR JI. 2001. Análises estatísticas no SAEG. Viçosa: UFV. 301p.

SAMPAIO IBM. 2002. Estatística aplicada à experimentação animal. 2. ed. Belo Horizonte: Fundação de Estudo e Pesquisa em Medicina Veterinária e Zootecnia. 256p.

SANTOS AA; CRISÓSTOMO JR; CARDOSO JE. 2004. Avaliação de híbridos de melão quanto as principais doenças nos Estados do Ceará e Rio Grande do Norte. Fortaleza: Embrapa Agroindústria Tropical. 14p.

SITTERLY WR. 1978. The powdery mildews of cucurbits. In: SPENCER, D. (ed). The powdery mildews. London: Academic Press. p.359-379.

STADNIK MJ; KOBORI RF; BETTIOL W. 2001. Oídios de cucurbitáceas. In: STADNIK MJ; RIVERA MC. (eds). Oidios. Jaguariúna: Embrapa Meio Ambiente. p.217-254.

VIANA FMP; SANTOS AA; FREIRE FCO; CARDOSO JE; VIDAL JC. 2001. Recomendações para o controle das principais doenças que afetam a cultura do melão na região Nordeste. Fortaleza: Embrapa Agroindústria Tropical. 22p.

YUSTE-LISBONA FJ; LOPEZ-SESÉ AI; GOMEZ-GUILLAMÓN ML. 2010. Inheritance of resistance to races 1,2 and 5 of powdery mildew in the melon TGR-1551. Plant Breeding 129: 72-75. 